J. G. Pinto, Vítor Monteiro, Henrique Gonçalves, Bruno Exposto, Delfim Pedrosa, Carlos Couto, João L. Afonso,

"Bidirectional Battery Charger with Grid-to-Vehicle, Vehicle-to-Grid and Vehicle-to-Home Technologies"

IEEE IECON Industrial Electronics Conference, pp.5934-5939, Vienna Austria, Nov. 2013.

http://ieeexplore.ieee.org/stamp/stamp.jsp?tp=\&arnumber $=6700108$

ISBN: 978-1-4799-0223-1

ISSN: $1553-572 \mathrm{X}$

DOI: $10.1109 /$ IECON.2013.6700108

This material is posted here with permission of the IEEE. Such permission of the IEEE does not in any way imply IEEE endorsement of any of Group of Energy and Power Electronics, University of Minho, products or services. Internal or personal use of this material is permitted. However, permission to reprint/republish this material for advertising or promotional purposes or for creating new collective works for resale or redistribution must be obtained from the IEEE by writing to pubs-permissions@ieee.org. By choosing to view this document, you agree to all provisions of the copyright laws protecting it.

(C) 2013 IEEE 


\title{
Bidirectional Battery Charger with Grid-to-Vehicle, Vehicle-to-Grid and Vehicle-to-Home Technologies
}

\author{
J. G. Pinto, Vítor Monteiro, Henrique Gonçalves, Bruno Exposto, Delfim Pedrosa, Carlos Couto, João L. Afonso \\ Centro Algoritmi - University of Minho - Guimarães, Portugal \\ E-mails: \{gabriel.pinto, vitor.monteiro, henrique.goncalves, bruno.exposto, delfim.pedrosa \\ carlos.couto, joao.l.afonso\}@algoritmi.uminho.pt
}

\begin{abstract}
This paper presents the development of an on-board bidirectional battery charger for Electric Vehicles (EVs) targeting Grid-to-Vehicle (G2V), Vehicle-to-Grid (V2G), and Vehicle-to-Home (V2H) technologies. During the G2V operation mode the batteries are charged from the power grid with sinusoidal current and unitary power factor. During the V2G operation mode the energy stored in the batteries can be delivered back to the power grid contributing to the power system stability. In the V2H operation mode the energy stored in the batteries can be used to supply home loads during power outages, or to supply loads in places without connection to the power grid. Along the paper the hardware topology of the bidirectional battery charger is presented and the control algorithms are explained. Some considerations about the sizing of the AC side passive filter are taken into account in order to improve the performance in the three operation modes. The adopted topology and control algorithms are accessed through computer simulations and validated by experimental results achieved with a developed laboratory prototype operating in the different scenarios.
\end{abstract}

Keywords-Bidirectional Battery Charger; Grid-to-Vehicle (G2V); Vehicle-to-Grid (V2G); Vehicle-to-Home (V2H)

\section{INTRODUCTION}

Electric Vehicles (EVs), represents a new concept in the transports sector around the world [1]. Consequently, the interest in technologies for EVs has significantly increased in the last years, resulting in several scientific publications concerning this subject [2][3][4]. It is expected that the market share of EVs will exponentially grow comprising $24 \%$ of the U.S. light vehicle fleet in 2030, representing 64\% light vehicle sales in this year [5]. In this context, the EVs battery charging process (Grid-to-Vehicle, G2V) must be regulated [9][10] to preserve the power quality in the power grids [11][12]. Nevertheless, with the proliferation of EVs a considerable amount of energy will be stored in their batteries, arising the opportunity of the energy flow in opposite sense (Vehicle-to-Grid, V2G) [6][7][8]. In the future smart grids, the interactivity with the EVs will be one of the key technologies, contributing to the power grid autonomous operation [13][14]. Nowadays, several projects related with smart grids are under development around the world [15]. Regarding this new approach, especially in homes equipped with charging points for EVs, besides the G2V and V2G operation modes the EVs can also operates as voltage source capable to feed the home loads. This technology, begins to be denominated in the literature as Vehicle-to-Home (V2H). As example of this new approach, Nissan presented the "LEAF-to-Home" system. This is a technology that uses energy from the Nissan Leaf batteries to supply the home loads through the "EV Power Station" unit [16]. Effectively, smart homes with energy management and efficiency solutions will be the first step to the smart grid evolution [17][18]. However, solutions like the "LEAF-to-Home" only allows deliver the stored energy in the batteries back to the home in the place where the equipment is installed. In this paper is proposed an on-board battery charger that enables the $\mathrm{V} 2 \mathrm{H}$ operation mode in the place where the EV is parked. This battery charger allows receive energy from the power grid $(\mathrm{G} 2 \mathrm{~V})$, and deliver back to the power grid part of the stored energy in the batteries (V2G), or provide energy to any load connected to the EV (V2H), in an isolated island mode.

In this sequence of ideas, the EVs can bring benefits to the home energy management, especially to feed priority loads during power outages and other emergencies. From the point of view of the power grid, EVs can bring benefits to ancillary services, compensation of the renewable energy sources intermittency (providing both backup, storage and load-shift). This new approaches are more relevant when looking that private vehicles are parked on average $93-96 \%$ of their lifetime [19], and most of the vehicles are at home between $8 \mathrm{pm}$ and 7 am [20]. The concept of the on-board bidirectional charger with $\mathrm{V} 2 \mathrm{G}$ and $\mathrm{V} 2 \mathrm{H}$ technologies is introduce in Fig. 1. When the $\mathrm{EV}$ is connected to the power grid the energy can flow to or from the EV batteries (G2V and V2G). In the absence of power grid or power outages, the EV can operates as voltages source to feed the desired loads. The system is not intended for a real-time energy backup, but has an auxiliary energy storage system. Thus, the transitions between the modes can be seamless.

\section{BidiRECTIONAL BATTERY CHARGER TOPOLOGY}

The presented battery charger is composed by two power converters that share a DC link. One is to interface the power grid and the other is to interface the traction batteries. In order to interface the power grid is used a full-bridge AC-DC bidirectional converter. This converter can operates as active

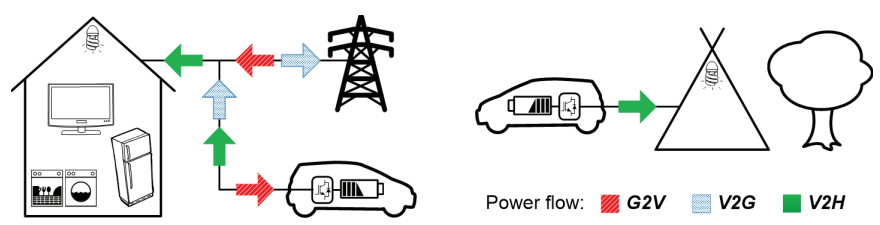

Fig. 1. Concepts of the bidirectional battery charger with G2V, V2G and $\mathrm{V} 2 \mathrm{H}$ technologies. 


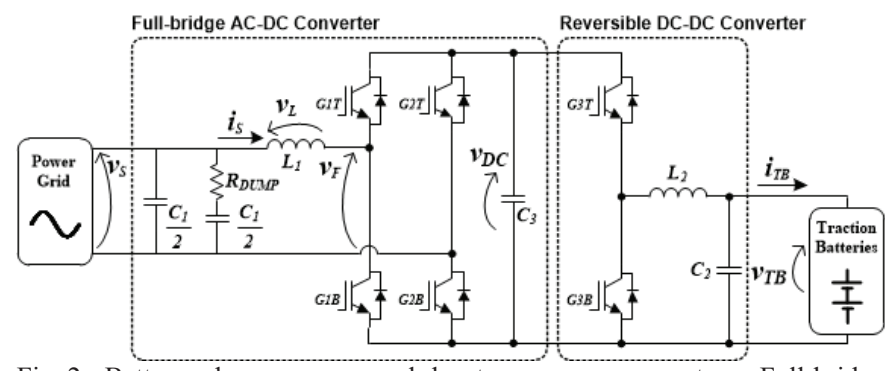

Fig. 2. Battery charger composed by two power converters: Full-bridge AC-DC bidirectional converter and Reversible DC-DC converter.

rectifier with sinusoidal current and unitary power factor during the G2V operation mode. During the V2G and V2H operation modes this power converter operates as inverter. In the V2G mode the converter operates as controlled current source to inject the required power in the power grid. In the $\mathrm{V} 2 \mathrm{H}$ mode, the converter operates as a controlled voltage source with true sine-wave output to feed the home loads.

In order to interface the batteries is used a reversible DC-DC converter. In the $\mathrm{G} 2 \mathrm{~V}$ operation mode this converter operates as buck converter to control the current and voltage during the current and voltage batteries charging stages, respectively. During V2G and V2H the converter operates as boost converter to elevate the batteries voltage to an adequate DC link voltage aiming to guarantee the proper operation of the full-bridge AC-DC bidirectional converter. The complete electric diagram of the bidirectional battery charger is presented in Fig. 2. Although using two bidirectional converters, the required hardware is equivalent to a controlled three leg IGBT bridge.

\section{CONTROL AlgORITHMS}

The control algorithms of the two converters is different in each of the three possible operation modes (G2V, V2G and $\mathrm{V} 2 \mathrm{H}$ ) as described follows.

\section{A. Grid-to-Vehicle (G2V) Operation Mode}

During this operation mode the full-bridge AC-DC bidirectional converter operates as active rectifier with sinusoidal current and unitary power factor. The reversible DC-DC converter operates as buck converter.

In order to accomplish with the maximum amplitude of the individual current harmonics specified by IEC 61000-3-2 standard, it is mandatory that the full-bridge AC-DC bidirectional converter controller must be synchronized with the power grid fundamental voltage. Therefore, a single-phase Phase-locked Loop (PLL) is the first algorithm implemented by the digital controller. To accomplish with this requirement a single-phase PLL in the $\alpha-\beta$ coordinates is used [21]. This algorithm produces two sine-waves with unitary amplitude shifted by $90^{\circ}: p l l_{\alpha}$ and $p l l_{\beta}$. When the PLL is synchronized with the power grid, the signal $p l l_{\alpha}$ corresponds to the direct component of the power grid fundamental voltage. This signal is used as input to the subsequent digital control algorithms.

The second control algorithm is responsible to calculate the reference current for the full-bridge AC-DC bidirectional converter. The amplitude of the reference current is achieved through the division of the reference active power by the power grid voltage, affected by the $p l l_{\alpha}$ signal. The reference active power is obtained through a PI controller designed to keep the DC link voltage regulated. In Fig. 3 it can be seen the control block diagram to generate the current reference $\left(i_{S} *\right)$. In order to synthesize the reference current calculated by the control algorithm, it is used a model predictive current control as presented in [22]. This current control uses the circuit model parameters and the information from previous samplings to calculate the voltage that the full-bridge AC-DC bidirectional converter must produce in each switching period, $k$, and can be resumed by:

$$
v_{F}[k]=v_{S}[k]-\frac{L_{I}}{T}\left(2 i_{S}{ }^{*}[k]-i_{S}{ }^{*}[k-1]-i_{S}[k]-i_{\text {Serror }}[k-1]\right),
$$

where, $v_{F}[k]$ is the reference voltage, $v_{S}[k]$ is the power grid voltage, $i_{S}[k]$ is the full-bridge produced current, and $i_{S}$ error $[k]$ the error between the reference and the produce current. The control algorithm is presented in Fig. 4.

The reference voltage calculated by the predictive current control algorithm is applied to a unipolar sinusoidal Pulse Width Modulator (PWM) with a $20 \mathrm{kHz}$ center aligned triangular carrier to obtain the IGBTs gate pulse patterns. A dead-time compensation methodology is used in order to be obtained a current with low harmonic distortion.

The DC link voltage is always higher than the traction batteries voltage and for this reason during the $\mathrm{G} 2 \mathrm{~V}$ operation mode the reversible DC-DC converter operates as buck converter. In order to perform the batteries charging process, most of the batteries manufacturers recommend two charging stages: constant current followed by constant voltage. The first stage consists in charging the batteries with constant current until the voltage reaches the recommended maximum voltage, and in the second stage the voltage is maintained constant until the current consumed by the batteries falls to a residual value. The EVs traction batteries are composed by a set of individual cells connected in series and parallel. It is usual to have a Battery Management System (BMS) to monitor each cell individually and that defines the charging stages. In order to

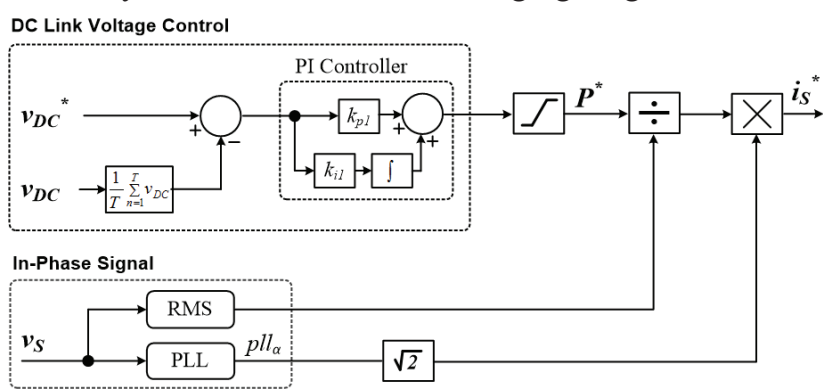

Fig. 3. Control block diagram to generate the current reference of the full-bridge AC-DC bidirectional converter.

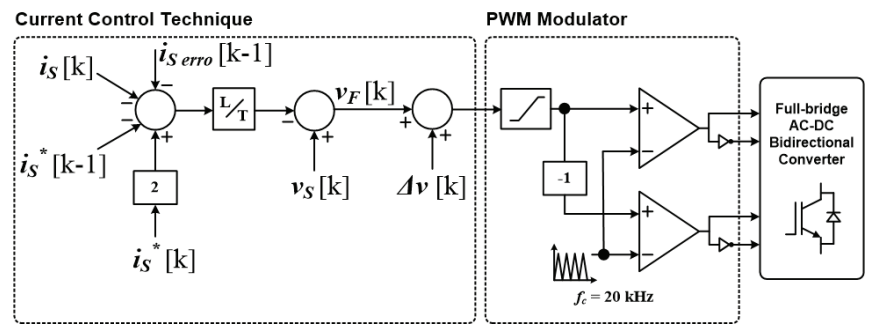

Fig. 4. Control block diagram of the current control technique. 
accomplish with the batteries manufacturers recommendations, the reversible DC-DC converter is controlled in both constant current and constant voltage stages as shown in Fig. 5.

During the constant current stage the reference current $\left(i_{T B}{ }^{*}\right)$ is compared with the actual current $\left(i_{T B}\right)$. The obtained current error feeds a PI controller that adjusts the output duty-cycle through a PWM modulator with a triangular carrier of $20 \mathrm{kHz}$. When the maximum voltage value recommended by the batteries manufacturer is reached the control algorithm changes to the constant voltage stage. In this stage a second PI controller is used to maintain constant the output voltage $\left(v_{T B}\right)$ of the reversible DC-DC converter according to the voltage reference $\left(v_{T B} *\right)$.

\section{B. Vehicle-to-Grid (V2G) Operation Mode}

The full-bridge AC-DC bidirectional converter operates as inverter with sinusoidal current and unitary power factor, and the reversible DC-DC converter operates as a boost converter.

As in the $\mathrm{G} 2 \mathrm{~V}$ operation mode, in the $\mathrm{V} 2 \mathrm{G}$ mode the full-bridge AC-DC bidirectional converter must be synchronized with the power grid fundamental voltage. As aforementioned the synchronization is obtained through a single-phase $\alpha$ - $\beta$ PLL in $\alpha-\beta$ coordinates. The active power to be delivered to the power grid is established as external input parameter received from a serial communication port in order to enable the collaborative integration of the EV in a smart grid context. Therefore, the control algorithm employed in the V2G operation mode is similar to the one used in the $\mathrm{G} 2 \mathrm{~V}$ operation mode. Aiming to synthesize the reference current correspondent to the active power to be delivered it was also used a predictive current control.

In order to the full-bridge AC-DC bidirectional converter deliver back to the power grid the energy stored in the traction batteries, the DC link voltage must be slightly greater than the peak value of the power grid voltage. For such intent, the reversible DC-DC converter has to operate as a boost converter, once the traction batteries voltage is smaller than the required to the DC link voltage.

The traction batteries voltage does not suffer significant variation during short time periods, consequently the regulation of the active power delivered back to the power grid can be done by the absorption of a constant current from the traction batteries. However, as the batteries voltage decreases along the discharging process it is necessary to increase the reference current to maintain the active power constant. The division of the reference active power $\left(P^{*}\right)$ by the traction batteries voltage $\left(v_{T B}\right)$ results in the traction batteries reference current $\left(i_{T B}{ }^{*}\right)$. The error between this current $\left(i_{T B}{ }^{*}\right)$ and the actual current $\left(i_{T B}\right)$ feeds a PI controller that adjusts the duty-cycle for a $20 \mathrm{kHz}$ PWM modulator, as shown in Fig. 6.

\section{Vehicle-to-Home (V2H) Operation Mode}

During the $\mathrm{V} 2 \mathrm{H}$ operation mode the full-bridge AC-DC bidirectional converter synthetizes a sine-wave voltage with the desired amplitude and frequency to feed the home loads. As in the $\mathrm{V} 2 \mathrm{G}$ operation mode the reversible DC-DC converter operates as a boost converter in order to maintain the DC link voltage with adequate amplitude for the proper operation of the full-bridge AC-DC bidirectional converter.
As the power absorbed by the loads is not constant and changes along the time, the power absorbed from the traction batteries must follow this load variation in order to maintain the DC link voltage regulated. Since the full-bridge AC-DC bidirectional converter only controls the output voltage amplitude and frequency, the regulation of the DC link voltage has to be done by the reversible DC-DC converter. The control algorithm of the full-bridge AC-DC bidirectional converter applied in this operation mode is presented in Fig. 7. The reference voltage is obtained from a sine table stored in the internal memory of the digital controller. In a voltage source inverter controlled in voltage mode, the control of the output voltage is done directly by adjusting the duty-cycle value of the PWM modulator. In order to enhance the quality of the produced waveform it is important to compensate the IGBTs dead-time effect and the voltage drop in the inductance of output filter, $L_{l}$. So, the voltage that the full-bridge AC-DC bidirectional converter must produce is the reference voltage minus the inductance voltage. In this control algorithm the inductance voltage is expressed with minus signal due to the signal arbiter as positive for the AC side current (positive from the grid to the power converter). In order to maintain the DC link voltage regulated is used the control algorithm presented in Fig. 8. The reference of the DC link voltage is compared with the actual voltage and the resultant error feeds a PI controller that adjusts the duty-cycle for a $20 \mathrm{kHz}$ PWM modulator.

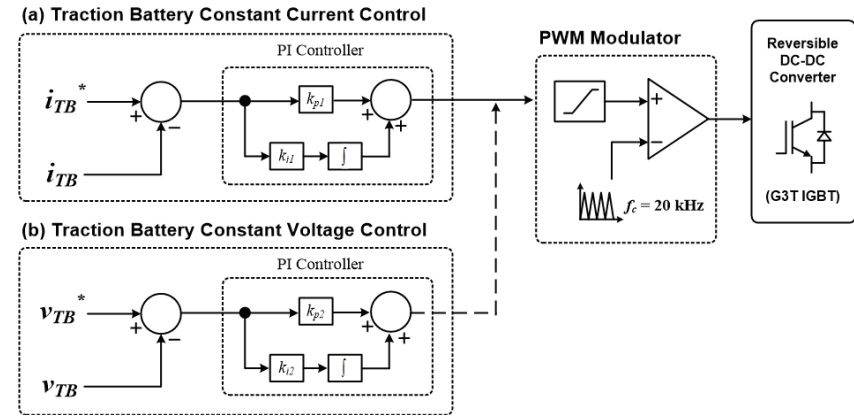

Fig. 5. Control block diagram of the reversible DC-DC converter digital controller: (a) Constant current stage; (b) Constant voltage stage.

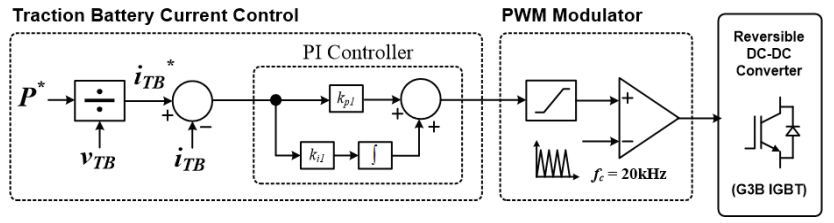

Fig. 6. Control block diagram of the reversible DC-DC converter digital controller during V2G operation mode.

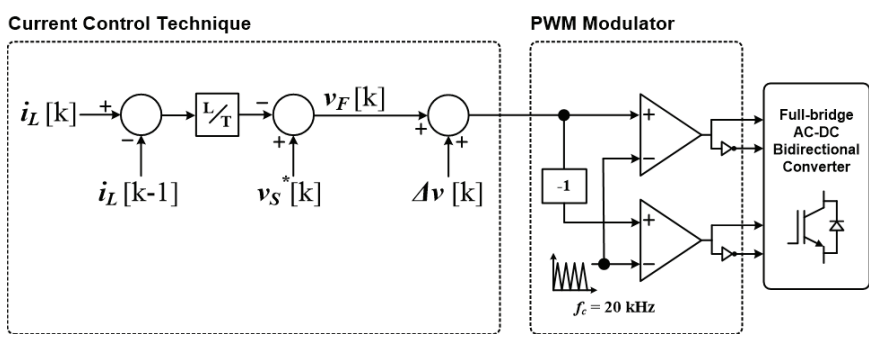

Fig. 7. Control block diagram of the full-bridge AC-DC bidirectional converter digital controller during $\mathrm{V} 2 \mathrm{H}$ operation mode. 


\section{Simulation of THE Bidirectional Charger}

In order to assess the hardware topology and the control algorithms, a simulation model of the presented bidirectional battery charger was developed with the PSIM 9.0 software.

In the $\mathrm{G} 2 \mathrm{~V}$ operation mode the power flows from the power grid to the batteries. During this mode it is expected that the battery charger works with sinusoidal current and unitary power factor in the $\mathrm{AC}$ side and with constant current or voltage in the batteries side, according with the battery charging algorithm.

The full-bridge AC-DC bidirectional converter operates with a $20 \mathrm{kHz}$ fixed frequency unipolar PWM switching technique, which results in a $40 \mathrm{kHz}$ output frequency. This converter is connected to the power grid (Fig. 2) through a second order low-pass LC passive filter. With the passive components of this filter, the high frequencies produced by the full-bridge AC-DC bidirectional converter are filtered. After some iterations a final value of $L_{l}=5 \mathrm{mH}$ and $C_{l}=2 \mu \mathrm{F}$ are selected as a compromise between the filter performance and component size. In order to smooth the gain response of the passive filter at the cutoff frequency, $C_{l}$ is split in two capacitors and is used a damping resistor $($ RDUMP $=128 \Omega)$ in series with one of them. Fig. 9 shows the frequency response of the filter. This filter presents a cutoff frequency around the $1.6 \mathrm{kHz}$. The reversible DC-DC converter operates as a buck converter with a fixed frequency of $20 \mathrm{kHz}$. The values of the passive components of the converter are selected to be $L_{2}=1.5 \mathrm{mH}$ and $C_{2}=700 \mu \mathrm{F}$. Once again the values of the components were established as compromise between the filter performance and component size. It is important that the capacitor $C_{2}$ presents low equivalent series resistor (ESR) in order to achieve low ripple in the batteries current.

In Fig. 10 are shown the simulation results obtained during the G2V operation mode of the bidirectional charger. Fig. 10 (a) shows the power grid voltage $\left(v_{S}\right)$ and the AC input current $\left(i_{S}\right)$ during two grid cycles. As it is possible to see, the input current is practically sinusoidal and is in phase with power grid voltage, validating the hardware topology and the control algorithms used in the full-bridge AC-DC bidirectional converter. Fig. 10 (b) shows the batteries charging current $\left(i_{T B}\right)$ and voltage $\left(v_{T B}\right)$ during the first two hours of operation. In order to obtain more realistic results, during this simulation is used a battery model parameterized to emulate a real battery pack. As it is possible to see in this figure the batteries current is maintained constant while the batteries voltage increases almost linearly, confirming the proper operation of the DC-DC reversible converter.

During the $\mathrm{V} 2 \mathrm{G}$ operation mode the power flows from the batteries to the power grid. It is expected that charger works with sinusoidal current in the AC side, as in the G2V mode. The reversible DC-DC converter must absorb a constant power from the batteries. So, the batteries current increases along the time to compensate the voltage drop inherent to the discharge process. In Fig. 11 are shown the simulation results obtained during the V2G operation mode. Fig. 11 (a) shows the power grid voltage $\left(v_{S}\right)$ and the AC output current $\left(i_{S}\right)$ during two grid cycles. Fig. 11 (b) shows the batteries current $\left(i_{T B}\right)$ and voltage $\left(v_{T B}\right)$ during two hours of operation. The simulation results are in accordance with the expected, validating the hardware topology and control algorithms used in the V2G operation mode.

As in the V2G, in the V2H operation mode the power flows from the batteries to the power grid. However, the operation of the power converters is totally different during this mode. The full-bridge AC-DC bidirectional converter must produce a sinusoidal voltage with the required amplitude and frequency to feed the home loads and the reversible DC-DC converter must regulate the DC link voltage.

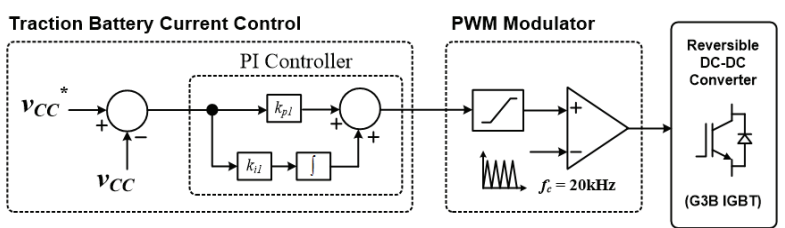

Fig. 8. Control block diagram of the reversible DC-DC converter digital controller during V2H operation mode.

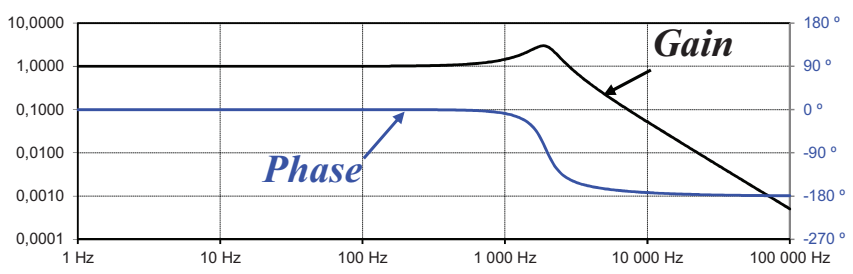

Fig. 9. Frequency response of the filter that interfaces the power grid with the full-bridge AC-DC bidirectional converter.

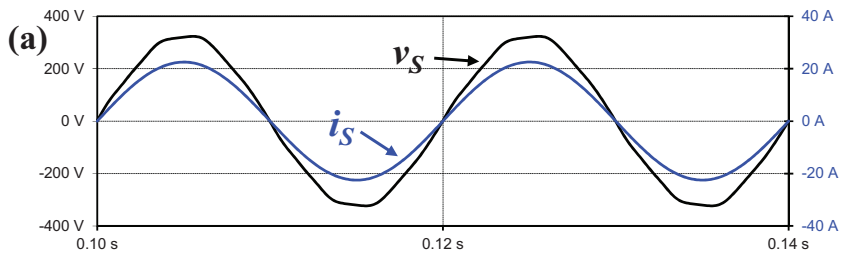

(b)

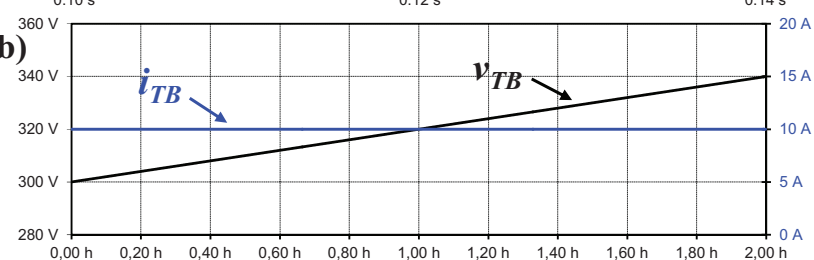

Fig. 10. Simulation results of the bidirectional battery charger during G2V operation mode: (a) Power grid voltage $\left(v_{S}\right)$ and AC input current $\left(i_{S}\right)$; (b) Batteries charging current $\left(i_{T B}\right)$ and voltage $\left(v_{T B}\right)$.

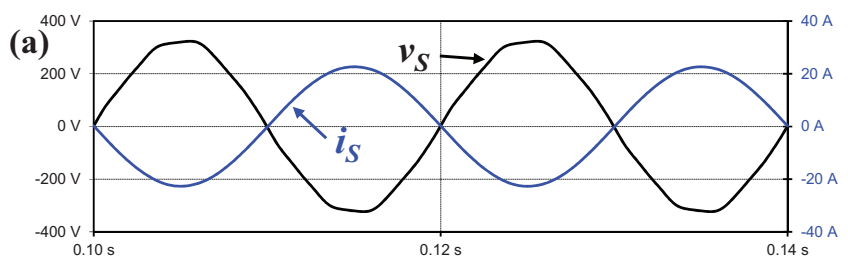

(b)

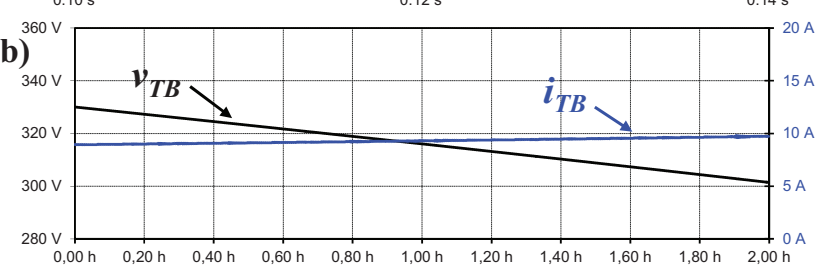

Fig. 11. Simulation results of the bidirectional battery charger during G2V operation mode: (a) Power grid voltage $\left(v_{S}\right)$ and AC input current $\left(i_{S}\right)$; (b) Batteries charging current $\left(i_{T B}\right)$ and voltage $\left(v_{T B}\right)$. 
It is important to highlight that the full-bridge AC-DC bidirectional converter in the $\mathrm{G} 2 \mathrm{~V}$ and $\mathrm{V} 2 \mathrm{G}$ operation modes operates as a current controlled voltage source inverter (VSI) and the output passive filter of the converter was optimized to allow a good current control within the operation range of the bidirectional battery charger. In the $\mathrm{V} 2 \mathrm{H}$ mode, the full-bridge AC-DC bidirectional converter operates as a voltage controlled VSI. Despite that the same output filter can be used, the quality of the produced voltage can be affected namely if they exist non-linear loads in the home. In order to analyze the influence of the output filter in the $\mathrm{V} 2 \mathrm{H}$ operation mode two simulations with different filters were performed. The first simulation uses the same passive filter LC used in the G2V and V2G operation modes, and the second ones uses a filter tuned to the same frequency but with different values of the passive components $\left(L_{l}=0.5 \mathrm{mH}, C_{l}=20 \mu \mathrm{F}\right.$ and $\left.\mathrm{R}_{\text {DUMP }}=16 \Omega\right)$. Fig. 12 presents the output voltage and load current of the bidirectional charger during the $\mathrm{V} 2 \mathrm{H}$ operation mode. In Fig. 12 (a) is shown the obtained results with $L_{l}=5 \mathrm{mH}$ and $C_{l}=2 \mu \mathrm{F}$, and in Fig. 12 (b) with $L_{l}=0.5 \mathrm{mH}$ and $C_{l}=20 \mu \mathrm{F}$. As it is possible to see, the output voltage is considerably better with the second LC passive filter. It is important to highlight that the load applied to the converter is the same for both cases, but the higher output impedance of the first passive filter limits the $d i / d t$ of the load current and therefore the load current waveform becomes slight different.

\section{DEVELOPED PROTOTYPE AND EXPERIMENTAL RESUltS}

In order to evaluate the battery charger under the different operation modes it was developed a laboratory prototype with the presented topology. A photo of the laboratory workbench is presented in Fig. 13. The power converters are composed by three half-bridge IGBT modules (SKM145GB066D) with three gate drivers (SKHI22AH4R), and a DC link composed by four capacitors $\left(C_{3}=1000 \mu \mathrm{F}-450 \mathrm{~V}\right)$. The output LC filters $\left(L_{1}\right.$, $C_{1}, L_{2}$, and $C_{2}$ ) were constructed using the same values of the simulation model. The digital control algorithms were implemented in a DSP TMS320F28335.

The developed bidirectional battery charger prototype was submitted to a set of operation tests during the three operation modes as shown in Fig. 14. The tests were performed with a set of 24 sealed 12 V 33 Ah Absorbed Glass Mat (AGM) batteries. In Fig. $14(\mathrm{a})$ is shown the power grid voltage $\left(v_{S}\right)$ and the current $\left(i_{S}\right)$ with an active power $\mathrm{P}=3.5 \mathrm{~kW}$, during the $\mathrm{G} 2 \mathrm{~V}$ operation mode. Fig. 14 (b) presents the power grid voltage $\left(v_{S}\right)$ and the current $\left(i_{S}\right)$ delivering back to the power grid an active power $\mathrm{P}=2 \mathrm{~kW}$, during the $\mathrm{V} 2 \mathrm{G}$ operation mode. As it can be seen in these figures, the current is sinusoidal with unitary power factor in both cases. Finally, in Fig. 14 (c) are shown the output voltage $\left(v_{S}\right)$ and the load current $\left(i_{S}\right)$, during the $\mathrm{V} 2 \mathrm{H}$ operation mode.

\section{CONCLUSIONS AND FUTURE WORK}

This paper presents the development of an on-board bidirectional battery charger for Electric Vehicles (EVs) capable of work in the operating modes Grid-to-Vehicle (G2V), Vehicle-to-Grid (V2G) and Vehicle-to-Home (V2H), which consist in important technologies for targeting the future smart grids scenario. The hardware topology and the control algorithms of the presented battery charger are validated
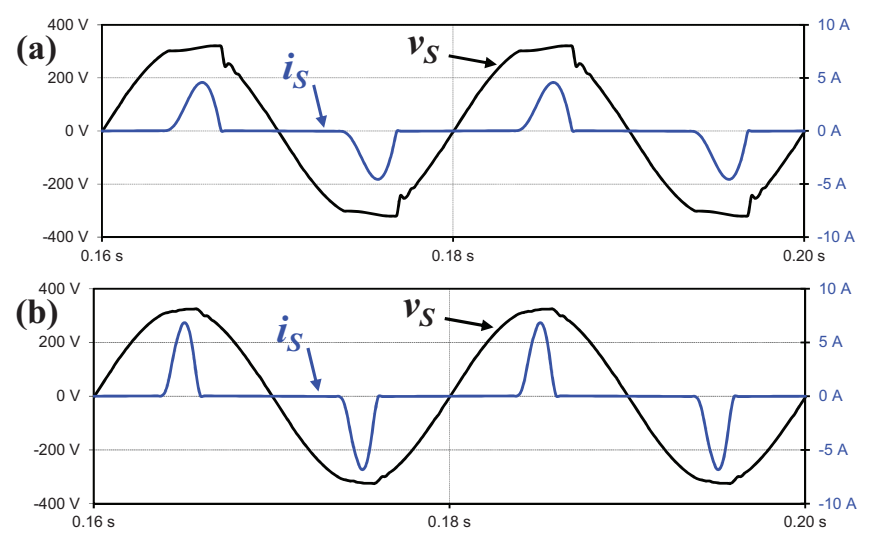

Fig. 12. Simulation results of the output voltage $\left(v_{S}\right)$ and $\mathrm{AC}$ input current $\left(i_{S}\right)$ of the bidirectional battery charger during $\mathrm{V} 2 \mathrm{H}$ operation mode: (a) with $L_{1}=5 \mathrm{mH}$ and $C_{1}=2 \mu \mathrm{F}$; (b) with $L_{1}=0.5 \mathrm{mH}$ and $C_{1}=20 \mu \mathrm{F}$.

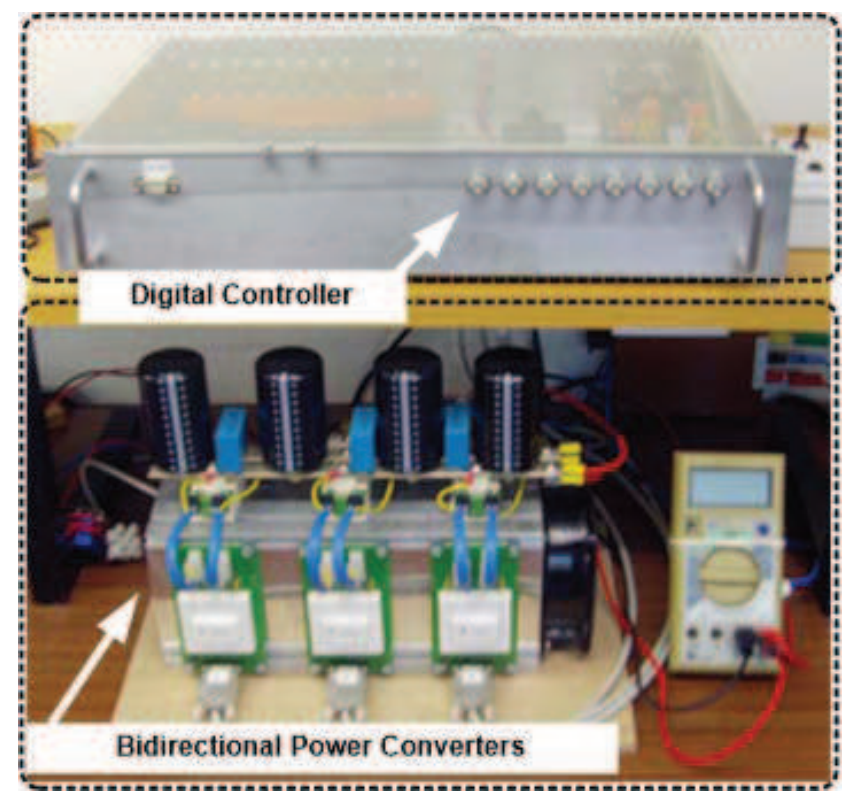

Fig. 13. Developed preliminary prototype in the laboratory workbench.

through computer simulations, using the PSIM software, and also through experimental results, achieved with a developed laboratory prototype. Since this work only intends to validate the topology and the control algorithms, the developed prototype that supports this work is intentionally oversized. The experimental results obtained with the three operation modes $(\mathrm{G} 2 \mathrm{~V}, \mathrm{~V} 2 \mathrm{G}$ and $\mathrm{V} 2 \mathrm{H})$ are in accordance with the expected, validating the viability of the proposed topology. As future work, the power converters will be redesigned in order to obtain a prototype with size and weight adequate to be integrated in an EV.

\section{ACKNOWLEDGMENT}

This work is financed by FEDER Funds, through the Operational Programme for Competitiveness Factors COMPETE, and by National Funds through FCT - Foundation for Science and Technology of Portugal, under the projects: FCOMP-01-0124-FEDER-022674, PTDC/EEA-EEL/104569/ 2008, and $\mathrm{AAC} \mathrm{n}{ }^{\circ} 36 / \mathrm{SI} / 2009 / 13844$. 

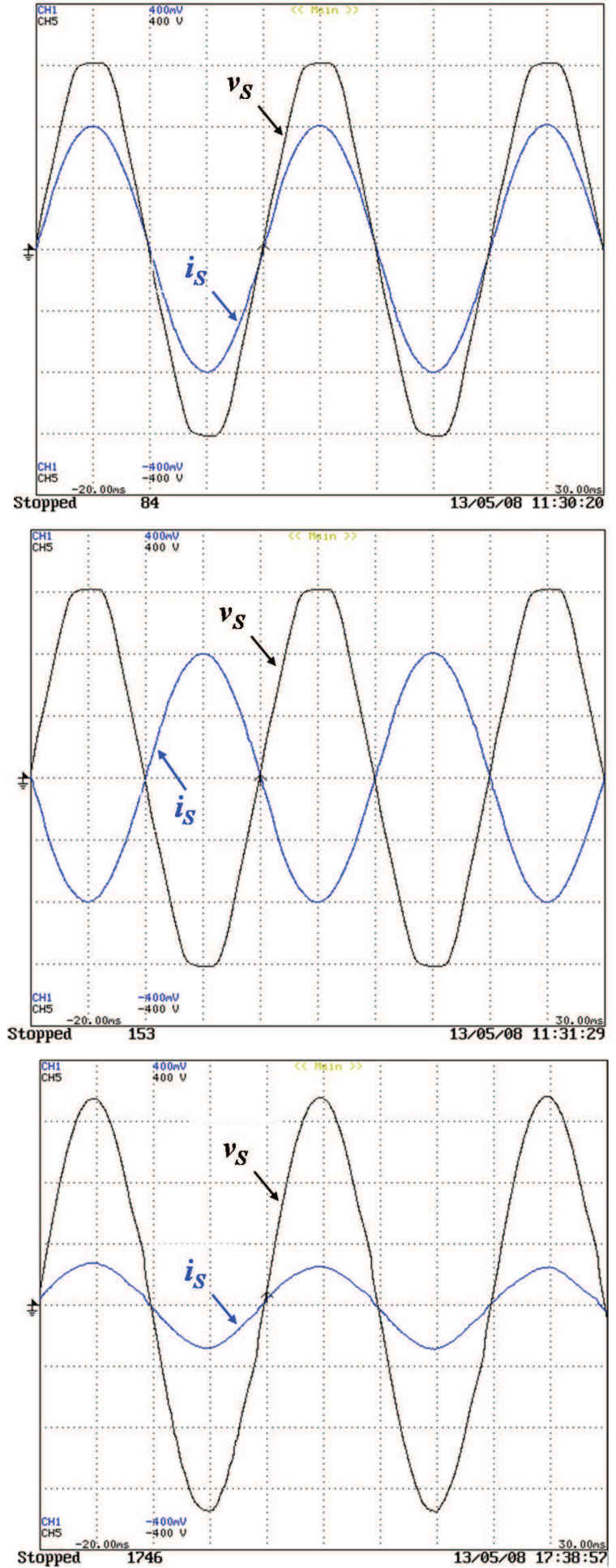

Fig. 14. Experimental results of the power grid voltage $\left(v_{S}-100 \mathrm{~V} / \mathrm{div}\right)$ and current $\left(i_{S}-10 \mathrm{~A} /\right.$ div) obtained during: (a) G2V operation mode; (b) V2G operation mode; and (c) V2H operation mode.

\section{REFERENCES}

[1] K. J. Dyke, N. Schofield, M. Barnes, "The Impact of Transport Electrification on Electrical Networks," IEEE Transactions on Industrial Electronics, vol.57, pp.3917-3926, 2010.
[2] C.C.Chan, "The State of the Art of Electric, Hybrid, and Fuel Cell Vehicles," Proceedings of the IEEE, vol.95, no.4, pp.704-718, Apr. 2007.

[3] A.Khaligh, Z.Li, "Battery, Ultracapacitor, Fuel Cell, and Hybrid Energy Storage Systems for Electric, Hybrid Electric, Fuel Cell, and Plug-In Hybrid Electric Vehicles: State of the Art," IEEE Transactions on Vehicluar Technology, vol.59, no.6, July 2010.

[4] C.Chan, A.Bouscayrol, K.Chen, "Electric, Hybrid, and Fuel-Cell Vehicles: Architectures and Modeling," IEEE Transactions on Vehicular Technology, vol.59, no.52, Fev. 2010.

[5] Thomas A. Becker, Ikhlaq Sidhu, Burghardt Tenderich, "Electric Vehicles in the United States A New Model with Forecasts to 2030," University of California, Berkeley, Center for Entrepreneurship \& Technology (CET), v.2.0, Aug. 2009.

[6] B. Kramer, S. Chakraborty, and B. Kroposki, "A review of plug-in vehicles and vehicle-to-grid capability," IECON 2008 - 34th Annual Conference of IEEE Industrial Electronics, pp. 2278-2283, Year 2008.

[7] W. Kempton, V. Udo, K. Huber, K. Komara, S. Letendre, S. Baker, D. Brunner, and N. Pearre, "A test of vehicle-to-grid (V2G) for energy storage and frequency regulation in the PJM system," University of Delaware. Year 2008.

[8] W. Kempton and J. Tomic, "Vehicle-to-grid power fundamentals: Calculating capacity and net revenue," Journal of Power Sources, vol. 144, pp. 268-279. Year 2005.

[9] K. Dyke, N. Schofield, M. Barnes, "The Impact of Transport Electrification on Electrical Networks," IEEE Transactions on Industrial Electronics, vol.57, pp.3917-3926, 2010.

[10] L.Jian, H.Xue, G.Xu, X.Zhu, D.Zhao, Z.Y.Shao, "Regulated Charging of Plug-in Hybrid Electric Vehicles for Minimizing Load Variance in Household Smart Micro-Grid," IEEE Transactions on Industrial Electronics, vol.60, pp.3218-3226, Aug. 2013.

[11] J. McDowall, "Conventional battery technologies-present and future," IEEE Power Engineering Society Summer Meeting, IEEE, 2000, pp. 1538-1540. Year 2000.

[12] A.Emadi, Y.J.Lee, K.Rajashekara, "Power Electronics and Motor Drives in Electric, Hybrid Electric, and Plug-In Hybrid Electric Vehicles," IEEE Transactions on Industrial Electronics, vol.55, pp.2237-2245, 2008.

[13] Vítor Monteiro, João C. Ferreira, Andrés A. Nogueiras Meléndez, João L. Afonso, "Electric Vehicles On-Board Battery Charger for the Future Smart Grids," in Technological Innovation for the Internet of Things, 1st ed., Luis M. Camarinha-Matos, Slavisa Tomic, Paula Graça, Ed. Springer, 2013, Chapter 38, pp.351-358.

[14] A.P.S.Meliopoulos, G.Cokkinides, R.Huang, E.Farantatos, S.Choi, Y.Lee, X.Yu, "Smart Grid Technologies for Autonomous Operation and Control," IEEE Transactions on Smart Grid, vol.2, no.1, March 2011.

[15] D.Sahin, T.Kocak, S.Ergut, C.Buccella, C.Cecati, G.P.Hancke, "Smart Grid and Smart Homes: Key Players and Pilot Projects," IEEE Industrial Electronics Magazine, vol.6, pp.18-34, Dec. 2012.

[16] Green Car Congress, "Nissan to launch the "LEAF to Home" V2H power supply system with Nichicon "EV Power Station" in June." [Online] Available: http://www.greencarcongress.com/2012/05/leafvsh20120530.html

[17] M.Moghadam, H.Taheri, "Electrical design of 21st century smart Homes," IEEE Iranian Conference on Smart Grids, 2012.

[18] L.Jiang, D.Liu, B.Yang, "Smart Home Research," IEEE International Conference on Machine Learning and Cybernetics, vol.2, pp.659-663, 2004.

[19] H. Turton, F. Moura, "Vehicle-to-Grid Systems for Sustainable Development: An Integrated Energy Analysis, " Technological Forecasting and Social Change, vol.75, issue:8, pp.1091-1108, 2008.

[20] K. Clement-Nyns, E. Haesen, J. Driesen, "The impact of charging PlugIn hybrid electric vehicles on a residential distribution grid," IEEE Transactions on Power Systems, Vol. 25, pp.371-380, Feb. 2010

[21] H.Carneiro, L.F.C.Monteiro, João L. Afonso, "Comparisons between Synchronizing Circuits to Control Algorithms for Single-Phase Active Converters," IEEE IECON Industrial Electronics Conference, pp.32293234, Nov. 2009.

[22] S. Orts-Grau, F. J. Gimeno-Sales, A. Abellán-García, S. Seguí-Chilet, J. C. Alfonso-Gil, "Improved Shunt Active Power Compensator for IEEE Standard 1459 Compliance," IEEE Transactions on Power Delivery, vol.25, pp.2692-2701, Oct. 2010. 